\title{
An efficient heat-shock protocol for transformation of Agrobacterium rhizogenes without spontaneous generation to antibiotic resistance
}

\author{
Juan Manuel Jiménez-Antaño ${ }^{1}$, Josefina Pérez-Vargas ${ }^{2}$, Armando Ariza-Castolo ${ }^{3}$, Octavio Gómez Guzmán ${ }^{1}$, \\ Graciano Calva-Calva ${ }^{* 1}$
}

${ }^{1}$ Biotecnología y Bioingeniería, Centro de Investigación y de Estudios Avanzados del Instituto Politécnico Nacional. Avenida Instituto Politécnico Nacional 2508, Colonia San Pedro Zacatenco, México Distrito Federal. CP 07360. , Mexico Tel: 52 (55) 57473800 Ext. 4348

${ }^{2}$ Tecnológico de Estudios Superiores de Ecatepec. División Ingeniería Bioquímica, Posgrado en Ingeniería Bioquímica. Av. Tecnológico S/N. Colonia Valle de Anáhuac, Ecatepec de Morelos, Estado de México, CP 55210. Tel: $52(55) 50002375$

${ }^{3}$ Química, Centro de Investigación y de Estudios Avanzados del Instituto Politécnico Nacional. Avenida Instituto Politécnico Nacional 2508, Colonia San Pedro Zacatenco, México Distrito Federal. CP 07360. Tel: 52 (55) 57473800 Ext. 3727

*Corresponding author: gcalva@cinvestav.mx

Abstract

Antibiotic resistance occurs when the use of antibiotics to treat bacterial infections or to select for transformed bacteria from in vitro cultures becomes ineffective. Although this phenomenon is primarily observed in medicine, it also affects the success of scientific research when bacterial-based genetic transformation experiments are performed. During the agrotransformation of plant cells, tissue, and organs, the acquisition of antibiotic resistance by Agrobacterium spp. has been widely observed, making it difficult to select for the transformed bacteria. The objective of this study was to develop a heat-shock protocol for the transformation of Agrobacterium rhizogenes without the spontaneous generation of antibiotic resistance, to increase its sensitivity and specificity to produce transgenic hairy roots. After the bacterium was transformed, it was cultured in liquid culture medium and plated on solid medium to isolate colonies. The genetic transformation of the bacteria and the plant tissue was verified by PCR and by $\beta$-glucuronidase assays. The reproducibility of the method was assessed among the $A$. rhizogenes strains LBA 9402, A4 and 15834 using streptomycin, kanamycin and ampicillin for selection.

Keywords: Bacterial transformation; Glucuronidase assay; plant vector; HPV-L1, RolB; VirD1; hairy roots, Brassica oleracea var. italica, broccoli.

Abbreviations: HPV16_Human papillomavirus type 16; HPV-L1_I1 gene or L1 protein; NLS_nuclear localization signal; X-Gluc_5bromo-4-chloro-3-indolyl glucuronide.

Introduction

In nature, the genetic transformation of plant cells and tissue occurs by infection of plant tissue with Agrobacterium tumefaciens or Agrobacterium rhizogenes, which transfer a DNA fragment (T-DNA) into the plant cells from tumorinducing (Ti) or root-inducing (Ri) plasmids, respectively (Hellens et al., 2000; Lee and Gelvin, 2008; Abarca-Grau et al., 2011). In scientific research, such T-DNA is typically modified and inserted into a binary plasmid to establish processes for the production of transgenic plants or transgenic plant cells, organs or tissue using Agrobacterium transformed by electroporation (den Dulk-Ras and Hooykaas, 1995; Morton and Fuqua, 2012) or freeze-thaw (Weigel and Glazebrook, 2006b) protocols. Thus, the transformation of Agrobacterium with the binary plasmid must be effective. The selection of the transformed bacteria is usually performed by culturing on solid and liquid media containing the proper antibiotics (Bent, 2006). At this step, spontaneous acquisition of antibiotic resistance by Agrobacterium has been detected (den Dulk-Ras and Hooykaas, 1995; Deeba et al., 2014) by mutation of antibiotic resistant genes that are chromosomally or $\mathrm{Ti} / \mathrm{Ri}$ plasmid localized (Hellens et al., 2000). In Agrobacterium, chromosomal genes involved in streptomycin, tetracycline, rifampicin, kanamycin, carbenicillin, and ampicillin resistance are the most commonly identified antibiotic resistance genes (Huang and Burr, 1999; Hellens et al., 2000; Lee and Gelvin, 2008). A high frequency of spontaneous streptomycin and tetracycline resistance in Agrobacterium has been reported. For streptomycin resistance, a chromosomal mutation that alters the bacterial ribosome, where streptomycin binds, appears to be the mechanism of antibiotic resistance (Huang and Burr, 1999; Demirci et al., 
2014; Munita and Arias, 2016). The acquisition of tetracycline resistance by $A$. tumefaciens is attributed to the presence of the tet $A$ gene in its chromosome (Luo and Farrand, 1999; Luo et al., 2001; Bent, 2006; Morton and Fuqua, 2012). Although this gene is repressed by tet $R$, in $A$. tumefaciens C5 there is an insertion element (IS426) within this gene that results in its inactivation and the expression of tet $A$, which leads to tetracycline resistant mutants (Luo et al., 2001; Morton and Fuqua, 2012). The mechanism of tetracycline resistance involves the transmembrane efflux of an antibiotic-metal complex (Luo and Farrand, 1999), and spontaneous mutants appear at frequencies of between $10^{-}$ ${ }^{6}-10^{-5}$. An example of plasmid-mediated resistance is that conferred by the plasmid RFS1010 for streptomycin, which carries homologs of the strA-strB resistance genes. These genes produce the enzyme aminoglycoside-3phosphotransferase and are associated with a Tn5393 transposon (Huang and Burr, 1999; Petrova et al., 2008; Munita and Arias, 2016).

In the complex ecological systems of natural environments, bacterial communities have multiple synergic strategies for resisting antibiotics, including vertical and horizontal gene transfer by transformation, conjugation and phage transduction (Arber, 2014; Landecker, 2016; Enault et al., 2017), biofilm formation (Vega and Gore, 2014), SOS bacterial response (Baharoglu and Mazel, 2014), transformation of the antibiotics into compounds that are ineffective at eliminating microorganisms (Koba et al., 2017). Another strategy is the interaction between different species, even from different kingdoms, via exogenous chemical signals that induce or increase the tolerance to antibiotics or compounds produced by other species in the community (Cohen et al., 2013; Vega et al., 2013). In nature, Agrobacterium produces biofilms as strategy to survive in disadvantageous environments, such as the presence of chemical and biological antimicrobial agents, permitting colonization of biotic (plant roots) and abiotic surfaces (synthetic materials) and growth in the presence of antibiotics and predators (Abarca-Grau et al., 2011; Heindl et al., 2014). An example of chemical communication has been reported for Salmonella typhimurium, which acquires antibiotic tolerance by the presence of indole produced by $E$. coli when cultured with the intestinal bacterial community (Vega et al., 2013). Interactions between species from different kingdoms occur during the agrotransformation processes of plants, both in nature and in laboratory experiments (den Dulk-Ras and Hooykaas, 1995; Hellens et al., 2000, Morton and Fuqua, 2012; Deeba et al., 2014). In addition, during the treatment of wastewater effluents using Agrobacterium, the resistance to antibiotics, such as neomycin, streptomycin and spectinomycin occurs in the natural microbial population by the overproduction of glycosyltransferases encoded by chromosomal genes, making the selection of the transformed bacteria difficult (Amos et al., 2014).

However, in simpler systems with single species, such as internal tissue infections or axenic in vitro cultures used for industrial processes and scientific research, strategies for resisting the acquisition of antibiotic resistance involve the individual abilities of bacteria that generate the phenotypic heterogeneity of each bacterial species (Morton and Fuqua, 2012; Cohen et al., 2013; Amos et al., 2014). This strategy may ensure the survival of some individuals from the population under the presence of antibiotics or other lethal stresses (Dhar and McKinney, 2007). It is uncertain why some individual bacterial cells can persist in the presence of antibiotics or lethal stress conditions, but their strategies include high genetic adaptability by spontaneous mutations and chromosomal rearrangements, changes in the metabolic profiles, phenomena related with structural changes in the cell wall and membranes (Maria-Neto et al., 2015), and high cellular densities. These phenomena have been reported for Salmonella enterica, Escherichia coli, and Pseudomonas aeruginosa and may be associated with alterations in the permeability of the outer cell membrane (Butler et al., 2010; Irazoki et al., 2017). The use of the high genetic adaptability strategy has been reported for Helicobacter pylori under laboratory conditions (Stingl et al., 2010; Corbinais et al., 2016) and in vivo for internal infections in humans (Corbinais et al., 2017), resulting in changes in membrane permeability, redox potential, and transporter proteins (Hu et al., 2016). Changes in the metabolic profiles may be induced by the composition and consistency of the culture medium, the addition of new metabolites or by cultivation in the presence of sublethal concentrations of antibiotics (Goh et al., 2002). For example, it has been reported that changes in the cell wall protein composition of Staphylococcus aureus depend on whether it is grown in solid or liquid medium (Cheung and Fischetti, 1988). Resistance to ampicillin by Pseudomonas was observed to be induced when it was grown in exogenous indole, which promoted the production of $\beta$-lactamase (Kim et al., 2017). Changes in the metabolic profiles associated with the production of phenolics and biofilms have been reported in nature and in experimental studies of $A$. tumefaciens and $A$. rhizogenes when grown axenically with chemical or antimicrobial agents (Heindl et al., 2014). In addition, metabolic profile changes have been observed throughout the process of genetic transformation of plant cells by infection and the transfer of T-DNA from plasmids to the plant cell genome, producing galls or hairy roots (Abarca-Grau et al., 2011).

Out of the abovementioned strategies for acquisition of antibiotic resistance, chromosomal mutations are more effective than mutation in plasmids (Bent, 2006), and although the use of a combination of antibiotics can help to reduce the problem (Morton and Fuqua, 2012), such mutations make the selection of the transformed bacteria difficult. However, as Bennett (2008) stated "Bacteria are not quiescent regarding their fates when faced with annihilation with antibiotics". Thus, the development of antibiotic-resistant bacteria is a phenomenon that has been widely observed, both in natural environments (Cohen et al., 2013; Amos et al., 2014) and in restrained or controlled conditions (Putrament et al., 1973; Landecker, 2016), affecting ecological and animal health, industrial processes, and scientific research experiments. The problem in the health of humans and animals has been reported for species that are clinically difficult to treat (Cohen et al., 2013; Ventola, 2015), while in industrial processes and in scientific research, it may affect the yield of genetically modified organisms and the experimental data by producing false positive results (Dhar and McKinney, 2007; Landecker, 2016). It is well-known, but practically unpublished, that the in vitro transformation of Agrobacterium spp. produces a high frequency of mutants that are resistant to the antibiotics used for the selection of the transformed bacteria 
(den Dulk-Ras and Hooykaas, 1995; Luo and Farrand, 1999; Hellens et al., 2000; Morton and Fuqua, 2012; Deeba et al., 2014). Therefore, in this study, a heat-shock protocol for the transformation of $A$. rhizogenes without the spontaneous generation of antibiotic resistance was developed to increase its sensitivity and specificity for the production of hairy root cultures of Brassica oleracea var. italica (broccoli).

\section{Results and Discussion}

\section{Transformation of Agrobacterium rhizogenes}

Two methods for the transformation of $A$. rhizogenes were used in this work. The first was a standard method, normally used in our laboratory and reported previously (JiménezAntaño et al., 2010; García-López et al., 2014),which combines the freeze thaw transfection procedure reported by Holsters et al., (1978), and the electroporation method reported by Weigel and Glazebrook (2006a). The second, stablished in this study and outlined in the material and methods section, results from a combination and modification of the reported protocols used for preparation of chemical competent cells of Agrobacterium (McCormac et al., 1998) and E. coli (Green and Rogers 2013), and the freeze-thaw method for the genetic transformation of $A$. tumefaciens (Höfgen and Willmitzer,1988).

The genetic transformation of Agrobacterium spp. with the pCGFPL1 construct, which holds the DNA from the complete $/ 1$ gene into the plasmid pCAMBIA 1305.1, by using the standard protocol, unexpectedly did not produced the expected transformants with the 11 gene (Table 1 ). Instead, this standard protocol produced a high quantity of bacteria resistant to kanamycin, the antibiotic used for the selection of the transformed bacteria, making impossible the selection of transformed colonies. From 30 transformants analyzed, none showed the presence of the 11 gene inserted in the pCGFPL1 construct, although the genes from the chromosome (Vir) and the pRi plasmid (Rol) were always present. Similar results were observed for bacteria transformed with the construct PPROEX-L1, which hold the ampicillin resistant gene but also the 11 gene. These results agree with reports that Agrobacterium hold chromosomal genes involved in streptomycin, tetracycline, rifampicin, kanamycin, carbenicillin, and ampicillin resistance genes and can show a high frequency of spontaneous streptomycin and tetracycline resistance (Huang and Burr, 1999; Hellens et al., 2000; Lee and Gelvin, 2008). As the spontaneous resistance shown by $A$. rhizogenes made not possible the selection of the transformants with the constructs holding 11 DNA, the transformation protocol was modified to improve the production of such transformed bacteria. Both methods involve two steps: the preparation of competent cells and the introduction of the plasmids into the $A$. rhizogenes competent cells; however these steps are different for each protocol. In the standard protocol the Agrobacterium chemical competent cells were prepared basically as reported for E. coli by Green and Rogers (2013), using LB medium and growing the cells at $28^{\circ} \mathrm{C}$ to reach an $\mathrm{A}_{600}=0.8$ 1. The competent cells were then transformed using the freeze-thaw method reported by Weigel and Glazebrook (2006b). In contrast, in the new method the competent cells are prepared by cultivation in YMB solid medium first, and then a single colony is grown in LB liquid medium to reach an $\mathrm{A}_{600}=0.8-1$, and the biomass is resupended in $\mathrm{CaCl}_{2} 20$ $\mathrm{mM}$ for heat-shock transformation as outlined in the material and methods section. Viability of the cells was highly affected by the transformation process (results not shown), but from $30-50$ single colonies transformed with the PCGFPL1 and the pPROEX-L1 plasmids analyzed by PCR showed the presence of the $I 1$ gene (Table 1 ). The method was verified for efficiency and reproducibility with several $A$. rhizogenes strains (Table 1 ). The results support that the new heat protocol was able to produce transformants of he A.rhizogenes strains without the spontaneous generation of antibiotic resistance observed with the standard method. The genetic transformation of the bacteria was then verified by PCR and by $\beta$-glucuronidase assays and used for the production of hairy root cultures of Brassica oleracea var. italica (broccoli).

\section{VirD1 and RolB gene amplification}

Colonies that were obtained after transformation in liquid medium were plated on solid medium, where the phenotypic characteristics of $A$. rhizogenes were observed, which included creamy white colonies with a mostly opaque center, similar to reports for other Agrobacterium species, such as $A$. vitis, for which colonies have a dark center with white margins (Allen and Holding, 1974; Matthysse, 2006). It was noted if the colony exhibited a watery appearance, which could be due to a high polysaccharide production (Matthysse, 2006). Polysaccharides are one of the major constituents of biofilms, assisting in cell-cell adhesion, cellsurface formation, and growth in a bacterial community, while also protecting cells from adverse conditions, such as immune system phagocytes, amoebae predators, and bacteriophages as well as chemical antimicrobials, such as antibiotics or disinfectants (Limoli et al., 2015). The obtained colonies were analyzed by PCR through amplification of the VirD1 and RolB encoding genes. In some cultures, smaller colonies that exhibited a white and dry appearance were observed, which when analyzed by PCR did not amplify the RolB or VirD1 encoding genes. All analyzed samples exhibiting the $A$. rhizogenes colony phenotype were positive for VirD1 and RolB gene amplification (Figure 1). All $A$. rhizogenes isolates transformed with pCAMBIA 1105.1, pCAMBIA 1305.1, pCGFPL1, and PCGFP2ATGL1 (Figure 1, lanes 1-4 respectively), amplified the expected $450 \mathrm{bp}$ fragment corresponding to VirD1-encoding gene, which was predicted from the in-silico analysis of the VirD1 gene sequence within the $\mathrm{pRI}$ plasmid (referenced in the methodology; GenBank Acc. No. NZ_CP019703). This contrasted with the negative $E$. coli control, where an E. coli strain lacking the pRI plasmid was used, and as expected, no amplification was observed (Figure 1 lane 5). The same bacterial cultures were used to amplify the RolB gene (Figure 1 lanes 6-8). Bands were observed of the expected size of $780 \mathrm{bp}$, as predicted by an in-silico analysis of the RolB gene with the T-DNA of the RI plasmid (GenBank accession no EF433766). The negative control confirmed the specificity of the technique, as there was no band in lane 10 since $E$. coli lacks the RI plasmid. The pPROEX-L1-transformed bacteria presented similar results, the observed 450 bp VirD1 gene band (Figure 2, lane 1) was not observed in the negative controls (lanes 2 and 3), while the 780 bp RolB gene band was observed (Figure 2, lane 4) but not in either of the 
Table 1. Antibiotic resistance and PCR amplifying of the VirD1, RolB and $I 1$ genes in three Agrobacterium rhizogenes strains (LBA9402, A4 and 15834) transformed with the several constructs ${ }^{1}$ and selected by using the standard protocols and the new method $^{2}$

\begin{tabular}{|c|c|c|c|c|c|c|c|c|c|c|c|c|}
\hline \multirow{3}{*}{$\begin{array}{l}\text { Antibiotic } \\
\text { resistance }\end{array}$} & \multicolumn{4}{|c|}{ LBA 9402} & \multicolumn{4}{|l|}{ A4 } & \multicolumn{4}{|c|}{15834} \\
\hline & \multicolumn{2}{|c|}{$\begin{array}{l}\text { Standard } \\
\text { Protocol }\end{array}$} & \multicolumn{2}{|c|}{ New Method } & \multicolumn{2}{|c|}{$\begin{array}{l}\text { Standard } \\
\text { Protocol }\end{array}$} & \multicolumn{2}{|c|}{ New Method } & \multicolumn{2}{|c|}{$\begin{array}{l}\text { Standard } \\
\text { Protocol }\end{array}$} & \multicolumn{2}{|c|}{ New Method } \\
\hline & $\begin{array}{l}\text { Vir } \\
\text { and } \\
\text { Rol }\end{array}$ & 11 & $\begin{array}{l}\text { Vir } \\
\text { and } \\
\text { Rol }\end{array}$ & 11 & $\begin{array}{l}\text { Vir } \\
\text { and } \\
\text { Rol }\end{array}$ & I1 & $\begin{array}{l}\text { Vir } \\
\text { and } \\
\text { Rol }\end{array}$ & 11 & $\begin{array}{l}\text { Vir } \\
\text { and } \\
\text { Rol }\end{array}$ & 11 & $\begin{array}{l}\text { Vir } \\
\text { and } \\
\text { Rol }\end{array}$ & 11 \\
\hline $\begin{array}{l}\text { Streptomycin } \\
\text { pCAMBIA1105.1 }\end{array}$ & + & - & + & - & + & - & + & - & + & - & + & - \\
\hline $\begin{array}{l}\text { Kanamycin } \\
\text { pCGFPL1 }\end{array}$ & + & - & + & + & + & - & + & + & + & - & + & + \\
\hline $\begin{array}{l}\text { Ampicillin } \\
\text { pPROEX-L1 }\end{array}$ & + & - & + & + & + & - & + & + & + & - & + & + \\
\hline
\end{tabular}

${ }^{1}$ The construct pCGFPL1 was prepared by transformation of the plasmid pCAMBIA 1305.1 with the $/ 1$ HPV16 complete gene (1596 bp). ${ }^{2}$ The new method is a combination and modification of the reported protocols used for preparation of competent cells (McCormac et al., 1998), and the freeze-thaw method (Höfgen and Willmitzer,1988), for the genetic transformation of $A$. tumefaciens. + and - indicate that the expected band in the PCR analyses of 30 bacterial colonies was or was not observed.

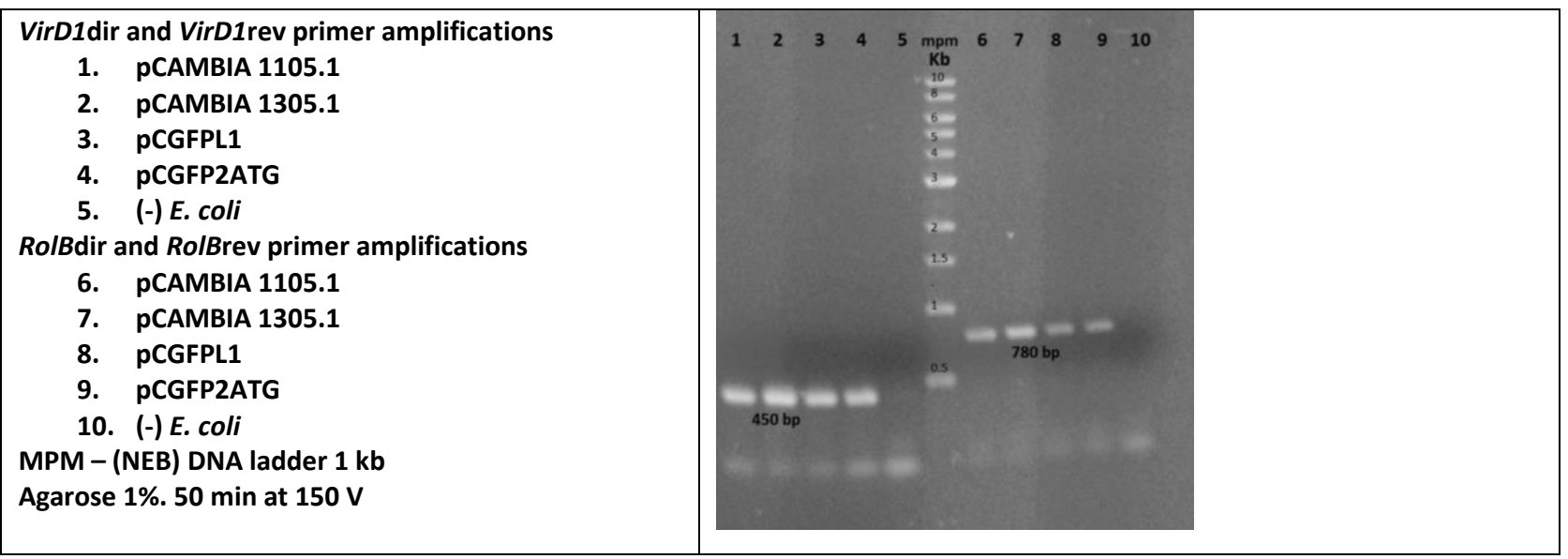

Fig 1. Amplification of the VirD1 (lanes 1-5) and RolB (lanes 6-10) genes in A. rhizogenes transformed with pCAMBIA 1105.1 (lanes 1 and 6), pCAMBIA 1305.1 (lanes 2 and 7), pCGFPL1 (lanes 3 and 8) and pCGFP2ATGL1 (lanes 4 and 9) resulted in the bands of the expected sizes of $450 \mathrm{bp}$ for VirD1 and $780 \mathrm{bp}$ on RolB, in contrast to their negative controls, where there was no amplification was observed (lanes 5 and 10).

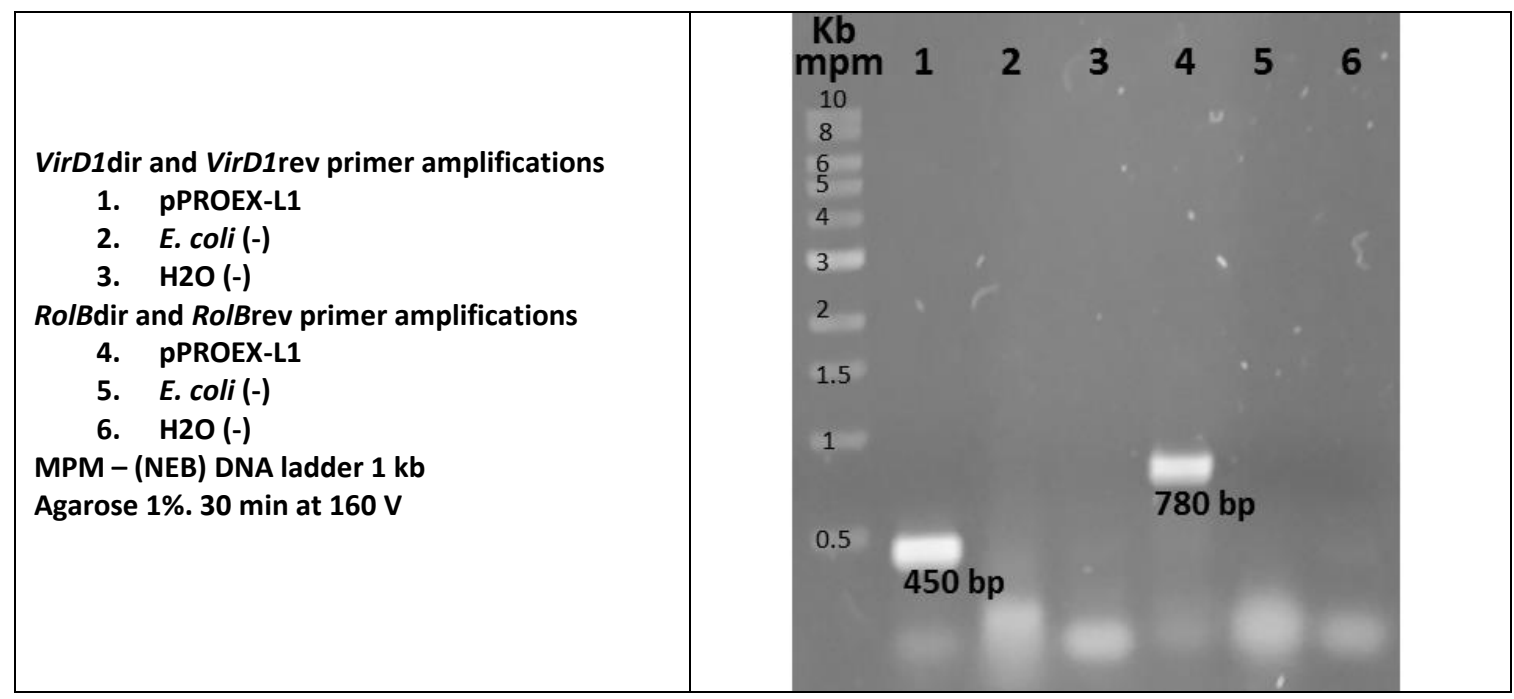

Fig 2. Amplification of VirD1 (lane 1) and RolB (lane 4) genes in A. rhizogenes transformed with pPROEX-L1. We did not observe the band in the negative controls, which used E. coli cells (lanes 2 and 5) or the control without cells or DNA that contained only water (lanes 3 and 6). 


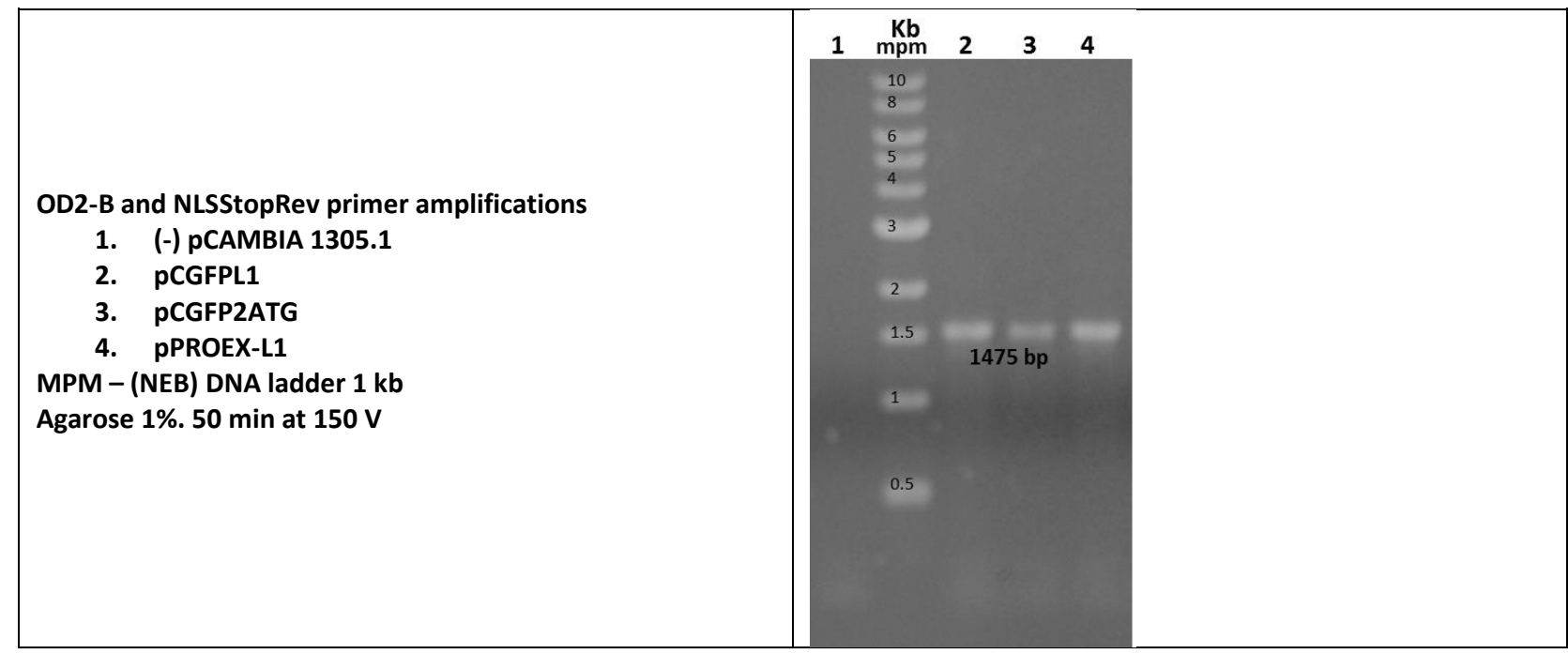

Fig 3. Amplification of $I 1$ gene from the constructs pCGFPL1, pCGFP2ATGL1 and pPROEX-L1 shows the presence of the $1475 \mathrm{bp}$ band in lanes 2-4, confirming the efficacy of the transformation method, contrasting the negative control (lane 1) in which we did not observe the $I 1$ band because the empty vector pCAMBIA 1305.1 without $I 1$ gene was used.

OD2B and NOSXbal primer amplifications

1. Genomic DNA pCGFPL1

2. GenOMIC DNA PCGFP2ATGL1

3. $\quad$ PCAMBIA $1305.1(-)$

4. PCGFPL1 (+)

$2 \mu \mathrm{L}$ of MPM - (NEB) DNA ladder $1 \mathrm{~kb}$

Agarose $1 \% .3 \mathrm{~min} 60 \mathrm{~V}$ and $30 \mathrm{~min}$ at $180 \mathrm{~V}$

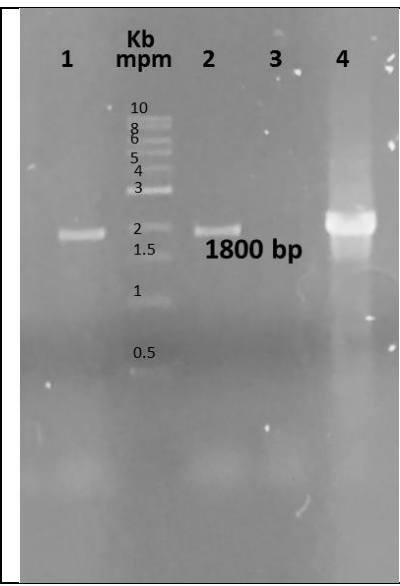

Fig 4. Amplification of the 11 gene with the NOS terminator, a fragment of the expected size was obtained in the root lineages analyzed (lane 1 and 2 ) and in the positive control (lane 4) and was not observed in the negative control (Lane 3).

\begin{tabular}{|c|l|l|l|l|}
\hline $\begin{array}{l}\text { Untransformed roots } \\
(-)\end{array}$ & $\begin{array}{l}\text { pCAMBIA 1105.1 } \\
\text { Transformed } \\
\text { roots }\end{array}$ & $\begin{array}{l}\text { pCAMBIA 1305.1 } \\
\text { Transformed } \\
\text { root }\end{array}$ & $\begin{array}{l}\text { pCGFPL1 } \\
\text { Transformed } \\
\text { roots }\end{array}$ & $\begin{array}{l}\text { pCGFP2ATG } \\
\text { Transformed } \\
\text { roots }\end{array}$ \\
\hline & &
\end{tabular}

Fig 5. Roots transformed with the pCAMBIA 1105.1 and pCAMBIA 1305.1 vectors and the roots transformed with the pCGFPL1 and PCGFP2ATGL1 constructs were positive for the $\beta$-glucuronidase assay, indicated by the blue staining that occurred in the roots, in contrast to the negative control (untransformed roots), which do not present the blue coloration. 
negative controls (Figure 2, lanes 5 and 6 ). The primers used, as well as the band of the expected size, are similar to the results obtained in other studies, such as for RolB (Hamill et al., 1991; Arshad et al., 2014; Harfi et al., 2016) and for VirD1 (Charlwood and Salem, 1999; Dehdashti et al., 2017).

\section{1 gene amplification}

Once it was shown that the bacteria obtained after transformation were $A$. rhizogenes by means of the amplification of the genes encoding VirD1 and RolB in the previous experiment, we proceeded to demonstrate that the transformation of these bacteria with the constructs carrying the L1 DNA. The cloned genes in the vectors, in this case, the 11 gene, were amplified from the pCGFPL1, pCGFP2ATGL1 and PPROEX-L1 constructs. The expected size band of $1475 \mathrm{bp}$ was obtained by amplifying a sequence within the 11 gene of HPV16 (Figure 3, lanes 2-4), which was predicted based on the in-silico sequence analysis. The size of the L1 protein gene is 1596 bp according to the GenBank sequence KC166220. In this PCR product, the DNA of the gene $I 1$ is truncated in the 5 ' sequence (lacking the first 78 bp), with amplification initiated from the second ATG. In addition, the gene does not have the $3^{\prime}$ region that encodes the nuclear localization sequence, which is $70 \mathrm{bp}$ in length. For this reason, the band size obtained was $~ 1475 \mathrm{bp}$, in contrast to the negative control in lane 1 , where as expected, the band was not obtained since it utilized plasmid DNA from the empty pCAMBIA 1305.1 plasmid without the cloned 11 gene. Similar results have been observed for the amplification size of the L1 proteinencoding gene, as well as the sequence of the primers that amplify the truncated gene at both ends without the first ATG or the NLS (Varsani et al., 2003). No PCR was performed on the transformations using the standard methods of heat shock and electroporation transformation and inoculation in solid medium since a cell lawn was obtained instead of isolated colonies. Isolated colonies were obtained when making dilutions after the transformation, but these isolates did not contain the cloned gene when analyzed by PCR, only testing positive for VirD1 and RolB amplification and not for the 11 protein-encoding gene.

\section{L1NOS amplification from genomic DNA of hairy roots}

Hairy roots transformed with either the complete $I 1$ gene or the truncated $/ 1$ gene lacking the first $78 \mathrm{bp}$ (starting at the second ATG) were obtained by Agrobacterium-mediated transformation. These hairy roots exhibited fast growth in a medium culture free of growth regulators and retained the typical hairy root phenotype, even after several generations of roots, similar as reported in the literature (Shanks and Morgan, 1999; Hodges et al., 2004; Zhou et al., 2007). Genomic DNA from these hairy roots was extracted, and the I1 gene was amplified with the NOS terminator by PCR to obtain fragments of the expected size of $1800 \mathrm{bp}$ (Figure 4). The expected size was based on the 1596 bp I1 gene sequence previously reported where the 11 gene was amplified. In this study, without considering the first 78 nucleotides (starting from the second ATG), and using a primer with the NOS terminator sequence obtained from plasmid pCAMBIA 1305.1, the in-silico analysis of the NOS sequence yield a $280 \mathrm{bp}$ fragment, that together with the
2ATG truncated gene, yield a DNA fragment of 1800 bp. Two hairy root lines were analyzed by PCR, a line transformed with pCGFPL1 (Figure 4, lane 1) and a line transformed with pCGFP2ATGL1 (Figure 4, lane 2). As a negative control, the empty vector pCAMBIA 1305.1 was used, which does not have 11 (Figure 4, lane 3). As can be seen in lane 3, no amplification of this fragment was observed. In contrast, the positive control, pCGFPL1 plasmid DNA extracted from $E$. coli that hold the 11 and the NOS terminator, yielded the expected fragment of $1800 \mathrm{bp}$ (Figure 4, lane 4). Although the pCGFPL1 construct has the complete 11 gene and pCGFP2ATGL1 has the truncated gene without the first $78 \mathrm{bp}$, an amplification fragment of the same size was obtained in the PCR because the first primer (OD2B) hybridizes to the second ATG, but does not amplify the first $78 \mathrm{bp}$, so in both PCGFPL1 and pCGFP2ATG the band is $1800 \mathrm{bp}$.

There are several studies where NOS is amplified to monitor the presence of transgenic organisms by amplification of the sequence of NOS producing DNA fragments shorter than those observed in the present study (Datukishvili et al., 2015; Fu et al., 2017); however, in the present work the NOS was cloned complete after the $I 1$ gene, in consequence the fragment obtained by PCR is longer.

\section{6-glucuronidase assay}

The roots transformed with Agrobacterium, in addition to presenting the genes cloned by agrotransformation, also produced heterologous proteins, such as the protein that confers hygromycin resistance. The evaluated roots could grow in the presence of this antibiotic, which in addition to the $\beta$-glucuronidase test indicates that the GUSPlus reporter gene was successfully expressed in these roots. Both the hygromycin resistance-conferring gene and GUSPlus are present within the pCAMBIA T-DNA, which integrated into the plant genome by $A$. rhizogenes. The use of PCAMBIA vectors, as well as the hygromycin resistance gene and the reporter gene of this plasmid, has been reported in other studies in which results similar to those reported in this study were been obtained (Gargul et al., 2017; Samara et al., 2017).

The substrate that is used for histochemical staining of $\beta$ glucuronidase activity in tissues and cells is 5-bromo-4chloro-3-indolyl glucuronide (X-Gluc), which forms a blue precipitate at the site of enzymatic activity. The product of the action of $\beta$-glucuronidase on X-Gluc (glucuronic acid) (Karcher, 2002) is not colored, therefore a derivative is used (indoxyl), which reacts with oxygen and produces, by oxidative dimerization, the insoluble dye $5,5^{\prime}$-dibromo- $4,4^{\prime}$ dichloro-indigo (Jefferson, 1987; Karcher, 2002). This dimerization is stimulated by atmospheric oxygen (Jefferson, 1987). In Figure 5, positive results for the analyzed samples can be observed for roots obtained from $A$. rhizogenes transformations with the different plasmids. Both pCAMBIA $1105.1,1305.1$ and the constructions derived from the latter plasmid (pCGFPL1 and pCGFP2ATGL1) present the coloration, indicating that the bacterium was transformed with these vectors. The positive result also indicated that these strains were able to process the T-DNA of both the Ri and PCAMBIA plasmids and were able to integrate it in the genome of the plant cells producing the transformed hairy 
root phenotype with the capacity to produce transgenic proteins such as $\beta$-glucuronidase. These results are similar to the phenotype of roots obtained by Henzi et al., 2000 and by García-López 2014.

\section{Materials and Methods}

\section{Genes, constructs, and GenBank accession numbers}

The pVAX1-L1 construct containing the HPV16 11 gene (GenBank accession number KC166220; 11 gene, 1596 bp) inserted into the pVAX1 vector was kindly provided by Dr. Monroy García A. The plant expression binary vectors pCAMBIA1105.1, and pCAMBIA 1305.1 (GenBank accession number AF354045), which confer bacterial resistance against streptomycin/spectinomycin and kanamycin, respectively, also contained the T-DNA that contains the plant gene conferring resistance to hygromycin (hptll), the GUSPlus reporter gene (gusA) and the cauliflower mosaic virus 355 promoter, which were obtained from CambiaLabs (Brisbane, Australia). Two constructs, pCGFPL1 and pCGFP2ATGL1, were prepared by transformation of the plasmid pCAMBIA 1305.1 with DNA from the 11 gene. The first was prepared by transformation of the plasmid pCAMBIA 1305.1 with the 11 HPV16 complete gene (1596 bp), and the second with the $/ 1$ gene truncated at the 5 '-end by the elimination of the first $78 \mathrm{bp}$ and starting from the second ATG, yielding a DNA fragment of $1518 \mathrm{pb}$. The construct PROEX-L1, prepared by insertion of the complete I1 gene between the $\mathrm{Ncol}$ and Hind III restriction sites in the pPROEX HTb B plasmid (Invitrogen, ThermoFisher Scientific, GenBank access number 10711018), was used as a control for evaluation of the ampicillin resistance.

\section{Bacterial strains}

The above plant binary vectors were prepared and cloned into Escherichia coli $\mathrm{DH} 5 \alpha$ by electroporation as previously described (Jiménez-Antaño et al., 2010 and 2015), and into A. rhizogenes strains LBA9402, A4, and 15834 carrying a wild pRi plasmid (GenBank accession number NZ_CP019703; VirD1 446 bp) with a Ri T-DNA RolB fragment (GenBank access number EF433766; RolB 788 bp) to establish hairy root cultures transformed with the L1 protein DNAs as established in the present work.

\section{Transformation of Agrobacterium rhizogenes}

Two methods for the transformation of $A$. rhizogenes were used in this work. A standard methods of heat shock reported by (Holsters et al., 1978; Weigel and Glazebrook, 2006b) and electroporation (Weigel and Glazebrook, 2006a), normally used in our laboratory and reported previously (Jiménez-Antaño et al., 2010; García-López et al., 2014), and by the new method stablished in this study.

\section{Standard protocol}

Transformation of $A$. rhizogenes was performed by the freeze thaw transfection procedure reported by Holsters et al., (1978), and the electroporation method reported by Weigel and Glazebrook (2006a), and has been normally used in our laboratory for transformation of $A$. rhizogenes
(Jiménez-Antaño et al., 2010; García López et al., 2013). In this method the competent cell were prepared as reported by Green and Rogers (2013), using the LB medium and growing the cell culture at $28{ }^{\circ} \mathrm{C}$ to reach $A_{600}=0.8-1$. The competent cells were then transformed with the respective plasmids using the freeze-thaw method reported by Weigel and Glazebrook (2006b).

\section{Heat-shock transformation protocol}

\section{Competent Agrobacterium rhizogenes cell preparation}

A loop from stock cultures of each strain of Agrobacterium rhizogenes maintained at $-70^{\circ} \mathrm{C}$ and tempered on ice was inoculated into $5 \mathrm{ml} \mathrm{YMB}$ liquid medium, incubated $12 \mathrm{~h}$ at $28^{\circ} \mathrm{C}$ in an orbital shaker at $200 \mathrm{rpm}$. A loop from the liquid medium was plated on YMB solid medium without antibiotic. A single colony was transferred to $5 \mathrm{~mL}$ LB liquid medium culture and incubated 24 hours at $28^{\circ} \mathrm{C}$ in an orbital shaker at $200 \mathrm{rpm}\left(\mathrm{A}_{600}=0.8-1\right)$. Samples of $1.5 \mathrm{~mL}$ were transferred to eppendorf tubes, and the biomass was washed $2 x$ by centrifugation 2 minutes at $9000 \mathrm{rpm}$ and resuspension in $1.5 \mathrm{~mL} \mathrm{CaCl} 20 \mathrm{mM}$. The biomass resuspended in $\mathrm{CaCl}_{2}$ was incubated on ice for 15 minutes and used for heat-shock transformation.

\section{Heat-shock transformation of Agrobacterium rhizogenes}

A volume of $100 \mu \mathrm{L}$ of the above competent Agrobacterium cells, pre-incubated on ice for 15 minutes, was added to a $1.5 \mathrm{ml}$ eppendorf tube containing $5 \mu \mathrm{L}(1 \mu \mathrm{g})$ of the plasmid or construct. The tube was sequentially submerged in liquid nitrogen for 2 minutes, then at $37^{\circ} \mathrm{C}$ for 5 minutes, 5 minutes on ice. Then $250 \mu \mathrm{L}$ of PSI medium culture (Tryptone $20 \mathrm{~g} / \mathrm{L}$, Yeast Extract $5 \mathrm{~g} / \mathrm{L}, \mathrm{MgCl}_{2} 5 \mathrm{~g} / \mathrm{L}, \mathrm{pH}$ 7.6), supplemented with $0.5 \%$ glucose, was added to the transformed cells and incubated at $28^{\circ} \mathrm{C}$ for 3 hours. The mixture was transferred to $5 \mathrm{~mL}$ of YMB liquid medium with the respective antibiotics and incubated for 48 hours. Growth was observed by turbidity presence. Samples of $1 \mu \mathrm{L}$ of the transformed culture was plated on YMB solid medium with the respective antibiotics and incubated for 48 hours at $28^{\circ} \mathrm{C}$ for selection of transformed bacterial colonies.

\section{Amplification of the RolB, VirD1 and I1 genes}

To demonstrate that the strains had been transformed, the following genes were amplified: RolB, with the primers RolBDir 5'-ATGGATCCCAAATTGCTATTCCTTCCACGA and RolBRev 5'-TTAGGCTTCTTTCTTCAGGTTTACTGCAGC, VirD1, with the primers VirD1Dir 5'-ATGTCGCAAGGACGTAAGCCCA and VirD1Rev 5'-GGAGTCTTTCAGCATGGAGCAA, and the $I 1$ gene, with the forward primer OD2-B 5'ATTGAAGATCTATGTCTCTTTGGCTGCC and the reverse primers NLSStopRev 5'-AAGGTCTCAAGCTTAACCTAATGTAAATTTTGG and NOSrevXbal 5'AATCTAGATTCCCGATCTAGTAACAT.

\section{Genomic DNA extraction}

Genomic DNA was extracted according to the protocol of (Healey et al,. 2014) with some modifications. Briefly, $50 \mathrm{mg}$ of fresh plant weight was ground in liquid nitrogen and transferred to an Eppendorf tube containing $400 \mu \mathrm{l}$ of 
extraction buffer ( 8 volumes of buffer per gram of sample). The samples were incubated for 30 minutes at $70^{\circ} \mathrm{C}$ with vortexing every 5 minutes, after which they were centrifuged at $13,200 \mathrm{rpm}$ for 5 minutes. Next, the supernatants were transferred to new tubes, and 1 volume of phenol:chloroform:isoamyl alcohol (25:24:1) was added. The samples were vortexed and then centrifuged at 13,200 rpm for 5 minutes, after which the aqueous fraction was transferred to a new tube and $3 \mu \mathrm{l}$ of $10 \mathrm{mg} / \mathrm{mL}$ RNase was added. The samples were incubated at $65^{\circ} \mathrm{C}$ for 1 hour, after which one volume of chloroform was added. The samples were vortexed and then centrifuged at 13,200 rpm for 5 minutes, after which the aqueous fraction was transferred to a new tube and 2 volumes of absolute ethanol were added. The DNA was allowed to precipitate at $-20^{\circ} \mathrm{C}$ for 1 hour, after which the tubes were centrifuged at 13,200 rpm for 5 minutes. The absolute ethanol was discarded and $70 \%$ ethanol was added, after which the tubes were incubated for 10 minutes at $-20^{\circ} \mathrm{C}$, centrifuged at $12,000 \mathrm{rpm}$ for 2 minutes, and then the ethanol was discarded and the pellet was allowed to dry for 15 minutes under a vacuum. Finally, the pellet was resuspended in $100 \mu \mathrm{L}$ of TE. The extraction buffer contained $100 \mathrm{mM}$ Tris- $\mathrm{HCl}(\mathrm{pH} 7.5), 25 \mathrm{mM}$ EDTA, $1.5 \mathrm{M} \mathrm{NaCl}, 2 \%$ CTAB (w/v), 2\% PVPP and $0.3 \%(\mathrm{v} / \mathrm{v}) \beta-$ mercaptoethanol, which was added immediately before use.

\section{Plant material}

Brassica oleracea var. italica (broccoli) seeds from the local market were surface sterilized with $5 \%$ sodium hypochlorite $(\mathrm{NaOCl})$ for 15 minutes, after which they were washed three times with sterile water. The washed seeds were transferred to flasks containing B5 medium culture (Gamborg et al., 1968) and then were incubated at $25-27^{\circ} \mathrm{C}$ in the darkness for 48 hours, followed by continuous illumination at 8400 lux for germination.

\section{Establishment of hairy root cultures and 6-glucuronidase assay}

The transformed roots were obtained and the $\beta$ glucuronidase assay was performed as previously described (Jiménez-Antaño et al., 2010; García-López 2014).

\section{Conclusion}

An efficient protocol for the transformation of $A$. rhizogenes, which does not present the problem of antibiotic resistance, was obtained for the antibiotics streptomycin, kanamycin and ampicillin. Although this method is more complex than the conventional transformation method, the problem of obtaining false positives by spontaneous resistance to antibiotics is avoided. The resulting bacteria have the ability to produce transgenic roots that, in addition to presenting the cloned genes, can produce heterologous proteins, which was demonstrated by the $\beta$-glucuronidase assay.

\section{Acknowledgments}

The first author was supported by a doctoral scholarship (209841) from the Consejo Nacional de Ciencia y Tecnologia (CONACYT Mexico).

\section{References}

Abarca-Grau AM, Penyalver R, López MM, Marco-Noales E (2011) Pathogenic and non-pathogenic Agrobacterium tumefaciens, $A$. rhizogenes and $A$. vitis strains form biofilms on abiotic as well as on root surfaces. Plant Pathol. 60:416-425.

Allen ON, Holding AJ (1974) Genus II. Agrobacterium Conn 1942,359. In: Buchanan RE, Gibbons NE (eds) Bergey's Manual of Determinative Bacteriology. 8th edn. The Williams and Wilkins Co., Baltimore, pp 264-267.

Amos GCA, Zhang L, Hawkey PM, Gaze WH, Wellington EM (2014) Functional metagenomic analysis reveals rivers are a reservoir for diverse antibiotic resistance genes. Vet Microbiol. 171:441-447.

Arber W (2014) Horizontal gene transfer among bacteria and its role in biological evolution. Life (Basel). 4:217.

Arshad W, Haq I-u, Waheed MT, Mysore KS, Mirza B (2014) Agrobacterium-mediated transformation of tomato with rolB gene results in enhancement of fruit quality and foliar resistance against fungal pathogens. Plos one. 9:e96979.

Baharoglu Z, Mazel D (2014) SOS, the formidable strategy of bacteria against aggressions. FEMS Microbiol rev. 38:11261145.

Bennett PM (2008) Plasmid encoded antibiotic resistance: acquisition and transfer of antibiotic resistance genes in bacteria. Brit J Pharmacol, 153:S347-S357.

Bent A (2006) Arabidopsis thaliana floral dip transformation method. In: Wang K. (eds) Agrobacterium protocols. Methods in molecular biology, vol 343. Humana Press, Totowa, NJ, pp 87-104

Butler MT, Wang Q, Harshey RM (2010) Cell density and mobility protect swarming bacteria against antibiotics. $P$ natl acad sci USA. 107:3776-3781.

Charlwood BV, Salem KMSA (1999) Genetic transformation of Pimpinella anisum (Anise). In: Bajaj YPS. (eds) Transgenic medicinal plants. Biotechnology in agriculture and forestry, vol 45. Springer, Berlin, Heidelberg, pp 222 236.

Cheung AL, Fischetti VA (1988) Variation in the expression of cell wall proteins of Staphylococcus aureus grown on solid and liquid media. Infect Immun. 56:1061-1065.

Cohen, NR, Lobritz MA, Collins JJ (2013) Microbial persistence and the road to drug resistance. Cell Host Microbe. 13:632-642.

Corbinais C, Mathieu A, Kortulewski T, Radicella JP, Marsin S (2016) Following transforming DNA in Helicobacter pylori from uptake to expression. Mol Microbiol. 101:10391053.

Corbinais C, Mathieu A, Damke PP, Kortulewski T, Busso D, Prado-Acosta M, Radicella JP, Marsin S (2017) ComB proteins expression levels determine Helicobacter pylori competence capacity. Sci Rep. 7:41495.

Dhar N, McKinney JD (2007) Microbial phenotypic heterogeneity and antibiotic tolerance. Curr Opin Microbiol. 10:30-38.

Datukishvili N, Kutateladze T, Gabriadze I, Bitskinashvili K, Vishnepolsky B (2015) New multiplex PCR methods for rapid screening of genetically modified organisms in foods. Front Microbiol. 6:757.

Deeba F, Hyder MZ, Shah SH, Naqvi SMS (2014) Multiplex PCR assay for identification of commonly used disarmed Agrobacterium tumefaciens strains. Springerplus, 3:358. 
Dehdashti SM, Acharjee S, Kianamiri S, Deka M (2017) An efficient Agrobacterium rhizogenes-mediated transformation protocol of Withania somnifera. Plant Cell Tiss Org. 128:55-65.

Demirci H, Murphy FV, Murphy EL, Connetti JL, Dahlberg AE, Jogl G, Gregory ST (2014) Structural analysis of base substitutions in Thermus thermophilus 16S rRNA conferring streptomycin resistance. Antimicrob Agents Ch. 58:4308-4317.

Den Dulk-Ras A, Hooykaas PJJ (1995) Electroporation of Agrobacterium tumefaciens. In: Nickoloff JA (eds) Plant cell electroporation and electrofusion protocols. Methods Mol Biol. 55: 63-72. Springer, Totowa, NJ

Enault F, Briet A, Bouteille L, Roux S, Sullivan MB, Petit M-A (2017) Phages rarely encode antibiotic resistance genes: a cautionary tale for virome analyses. Isme J. 11:237-247.

Fu W, Wei S, Wang C, Du Z, Zhu P, Wu X, Wu G, Zhu S (2017) A temperature-tolerant multiplex elements and genes screening system for genetically modified organisms based on dual priming oligonucleotide primers and capillary electrophoresis. Food Chem. 229: 396-402.

Gamborg OL, Miller RA, Ojima K (1968) Nutrient requirements of suspension cultures of soybean root cells. Exp Cell Res. 50:151-158.

García-Lopez E, Ramirez-Ramírez EG, Gómez-Guzman O, Calva-Calva G, Ariza-Castolo A, Perez-Vargas J, MartínezRodriguez HG (2014) MALDI-TOF characterization of hGH1 produced by hairy root cultures of Brassica oleracea var. italic grown in an airlift with mesh bioreactor. Biotechnol Progr. 30:161-171.

Gargul JM, Mibus H, Serek M (2017) Characterization of transgenic kalanchoë and petunia with organ-specific expression of GUS or GA 2 ox genes led by the deletion BOX-I version (dBI) of the PAL1 promoter. J Plant Growth Regul. 36:424-435.

Goh E-B, Yim G, Tsui W, McClure J, Surette MG, Davies J (2002) Transcriptional modulation of bacterial gene expression by subinhibitory concentrations of antibiotics. Proc Natl Acad Sci USA. 99:17025-17030.

Green R, Rogers EJ (2013) Transformation of chemically competent E. coli. Method Enzymol. 529:329-336.

Hamill JD, Rounsley S, Spencer A, Todd G, Rhodes MJC (1991) The use of the polymerase chain reaction in plant transformation studies. Plant Cell Rep. 10:221-224.

Harfi B, Khelifi-Slaoui M, Bekhouche M, Benyammi R, Hefferon K, Makhzoum A, Khelifi L (2016) Hyoscyamine production in hairy roots of three Datura species exposed to high-salt medium. In Vitro Cell Dev-PI. 52:92-98.

Healey A, Furtado A, Cooper T, Henry RJ (2014) Protocol: a simple method for extracting next-generation sequencing quality genomic DNA from recalcitrant plant species. Plant Methods. 10:21-21.

Heindl JE, Wang Y, Heckel BC, Mohari B, Feirer N, Fuqua C (2014) Mechanisms and regulation of surface interactions and biofilm formation in Agrobacterium. Front plant sci. 5.

Hellens R, Mullineaux P, Klee H (2000) Technical focus: a guide to Agrobacterium binary Ti vectors. Trends Plant Sci. 5:446-451.

Henzi MX, Christey MC, McNeil DL (2000) Factors that influence Agrobacterium rhizogenes-mediated transformation of broccoli (Brassica oleracea L. var. italica). Plant Cell Rep. 19:994-999.
Hodges LD, Cuperus J, Ream W (2004) Agrobacterium rhizogenes GALLS protein substitutes for Agrobacterium tumefaciens single-stranded DNA-binding protein VirE2. J Bacteriol. 186:3065-3077.

Höfgen R, Willmitzer L (1988) Storage of competent cells for Agrobacterium transformation. Nucleic Acids Res. 16:9877.

Holsters M, de Waele D, Depicker A, Messens E, van Montagu M, Schell J (1978) Transfection and transformation of Agrobacterium tumefaciens. Mol Gen Genet. 163:181-187.

Hu Y, Zhang M, Lu B, Dai J (2016) Helicobacter pylori and antibiotic resistance, a continuing and intractable problem. Helicobacter. 21:349-363.

Huang TC, Burr TJ (1999) Characterization of plasmids that encode streptomycin-resistance in bacterial epiphytes of apple. J Appl Microbiol. 86:741-751.

Irazoki O, Campoy S, Barbé J (2017) The transient multidrug resistance phenotype of Salmonella enterica swarming cells is abolished by sub-inhibitory concentrations of antimicrobial compounds. Front Microbiol. 8.

Jefferson R (1987) Assaying chimeric genes in plants: The gus gene fusion system. Plant Mol Biol Rep. 5:387-405.

Jiménez-Antaño JM, Montes Horcasitas MdC, Ramos Ramírez EG, Esparza García FJ, Ariza Castolo A, Pérez Vargas J, Gómez Guzmán O, Calva Calva G (2015) Expresión de la proteína L1 del VPH en Escherichia coli y raíces transformadas de brócoli CENIC ciencias biólogicas 46:402-409.

Jiménez-Antaño JM, Montes Horcasitas MdC, Ramos Ramírez EG, Ariza Castolo A, Pérez Vargas J, Gómez Guzmán O, Calva Calva G (2010) Cultivo de raíces aéreas de brócoli transformadas con la proteína L1 del virus del papiloma humano. CENIC Ciencias Biólogicas. 41:1-9.

Karcher S (2002) Blue plants: transgenic plants with the gus reporter gene. ABLE 23: 29-42.

Kim J, Shin B, Park C, Park W (2017) Indole-induced activities of $\beta$-lactamase and efflux pump confer ampicillin resistance in Pseudomonas putida KT2440. Front Microbiol. 8: 433.

Koba O, Golovko O, Kodešová R, Fér M, Grabic R (2017) Antibiotics degradation in soil: A case of clindamycin, trimethoprim, sulfamethoxazole and their transformation products. Environ Pollut. 220, Part B:1251-1263.

Landecker $H$ (2016) Antibiotic resistance and the biology of history. Body Soc. 22(4): 19-52.

Lee LY, Gelvin, SB (2008) T-DNA binary vectors and systems. Plant Physiol. 146:325-332.

Limoli DH, Jones CJ, Wozniak DJ (2015) Bacterial Extracellular Polysaccharides in Biofilm Formation and Function. In: Ghannoum $M$, Parsek $M$, Whiteley $M$, Mukherjee P (eds) Microbial Biofilms. 2nd edn, ASM Press, Washington, DC. pp 223-247.

Luo Z-Q, Farrand SK (1999) Cloning and characterization of a tetracycline resistance determinant present in Agrobacterium tumefaciens C58. J Bacteriol. 181:618-626.

Luo ZQ, Clemente TE, Farrand SK (2001) Construction of a derivative of Agrobacterium tumefaciens C58 that does not mutate to tetracycline resistance. Mol Plant Microbe. 14:98-103. 
Maria-Neto S, de Almeida KC, Macedo MLR, Franco OL (2015) Understanding bacterial resistance to antimicrobial peptides: From the surface to deep inside. Biochim Biophys Acta. 1848:3078-3088.

Matthysse AG (2006). The genus Agrobacterium. In: Dworkin M, Falkow S, Rosenberg E, Schleifer K-H, Stackebrandt E (eds) The prokaryotes: Volume 5: Proteobacteria: Alpha and beta subclasses. Springer New York, New York, NY, pp 91-114.

McCormac AC, Elliott MC, Chen DF (1998) A simple method for the production of highly competent cells of Agrobacterium for transformation via electroporation. Mol Biotechnol. 9:155-159.

Morton ER, Fuqua C (2012) Unit 3D.2 Genetic manipulation of Agrobacterium. Curr Protoc Microbiol .

Munita JM, Arias CA (2016) Mechanisms of antibiotic resistance. In: Kudva I, Cornick $\mathrm{N}$, Plummer $\mathrm{P}$, Zhang $\mathrm{Q}$, Nicholson T, Bannantine J, Bellaire B (eds) Virulence mechanisms of bacterial pathogens. 5th edn. ASM Press, Washington, DC. pp 481-511

Petrova MA, Gorlenko ZM, Soina VS, Mindlin SZ (2008) Association of the strA-strB genes with plasmids and transposons in the present-day bacteria and in bacterial strains from permafrost. Russ J Genet+. 44:1116-1120.

Putrament A, Baranowska H, Prazmo W (1973) Induction by manganese of mitochondrial antibiotic resistance mutations in yeast. Mol Gen Genet. 126:357.

Samara S, Singh B, John A, Venkateswar T (2017) Genetic transformation of indica rice varieties involving $A m-S O D$ gene for improved abiotic stress tolerance. Saudi J Biol Sci.
Shanks JV, Morgan J (1999) Plant 'hairy root' culture. Curr Opin Biotech. 10:151-155.

Stingl K, Muller S, Scheidgen-Kleyboldt G, Clausen M and Maier B (2010) Composite system mediates two-step DNA uptake into Helicobacter pylori. Proc Natl Acad Ssci USA. 107:1184-1189.

Varsani A, Williamson A-L, Rose RC, Jaffer M, Rybicki EP (2003) Expression of Human papillomavirus type 16 major capsid protein in transgenic Nicotiana tabacum cv. Xanthi. Arch Virol. 148:1771-1786.

Vega NM, Allison KR, Samuels AN, Klempner MS, Collins JJ (2013) Salmonella typhimurium intercepts Escherichia coli signaling to enhance antibiotic tolerance. Proc Natl Acad Sci USA. 110:14420-14425.

Vega NM, Gore J (2014) Collective antibiotic resistance: mechanisms and implications. Curr Opin Microbiol. 21:2834.

Ventola CL (2015) The antibiotic resistance crisis: Part 1: Causes and threats. Pharmacy Therapeutics. 40:277-283

Weigel D and Glazebrook J (2006a) Transformation of Agrobacterium using electroporation. CSH Protoc. 2006(7): 1-13.

Weigel D and Glazebrook J (2006b) Transformation of Agrobacterium using the freeze-thaw method. CSH Protoc. 2006(7): 1031-1036.

Zhou X, Wu Y, Wang X, Liu B, Xu H (2007) Salidroside production by hairy roots of Rhodiola sachalinensis obtained after transformation with Agrobacterium rhizogenes. Biol Pharm Bull. 30:439-442. 